\title{
Teaching the Youth and Adults through Education with Production: The Case Study of Tiger Kloof Educational Institution
}

\author{
Akwasi Arko-Achemfuor \\ University of South Africa, South Africa \\ aachea@unisa.ac.za
}

Doi:10.5901/mjss.2014.v5n1p607

\section{Abstract}

Education plays a pivotal role in teaching people in society so that they can bring about changes in their own lives and that of their communities. The types of education that are provided by various educational institutions across the world are mostly theoretical which makes it difficult for learners to apply the knowledge they acquire in practical ways. The outcomes-based education (OBE) approach which a lot of countries are applying in recent times places emphasis on learning outcomes that ensure that learners acquire skills, attitudes, knowledge and values that can be applied in various life situations. The founders of Tiger Kloof Educational Institution over 100 years ago applied the principle of education with production in teaching their learners who happened to be the youth and adults. When the school was re-opened in 1995 after its closure for over 25 years, academic and a few vocational subjects have been introduced as well as practical productive activities such as plumbing, carpentry, brick laying as well as the raising of vegetable gardens and rearing of cattle. The school is involved in a lot of practical and productive activities in generating funds and producing some of the food that is used to feed the students in the boarding house. The qualitative method using interviews was used to ascertain how the concept is being applied at Tiger Kloof. The study found the practice viable and recommends if for adoption in other educational institutions across Africa.

Keywords: Education, production, farming, adults, youth

\section{Introduction}

Education plays a pivotal role in teaching people in society so that they can bring about changes in their own lives and that of their communities. The types of education that are provided by various educational institutions across the world are mostly theoretical which makes it difficult for learners to apply the knowledge they acquire in practical ways. The outcomes-based education (OBE) approach which a lot of countries are pursuing in recent times places emphasis on learning outcomes that ensure that learners acquire skills, attitudes, knowledge and values that can be applied in various life situations. The founders of Tiger Kloof Educational Institution over 100 years ago applied the principle of education with production in teaching their learners who happened to be the youth and adults. The concept of education with production is closely related to the notion of school enterprise. School enterprise or education with production according to Singh (1998) takes into account the notion of market production with vocational learning. Economists normally define production as the creation of utilities or the creation of goods and services for satisfying wants. When the Tiger Kloof Educational Institution was re-opened in 1995 after its closure for over 25 years, academic and a few vocational subjects have been introduced as well as practical productive activities such as plumbing, carpentry, brick laying as well as the raising of vegetable gardens and rearing of cattle.

The school is involved in a lot of practical and productive activities in generating funds and producing some of the food that is used to feed the students in the boarding house and engaging in the repairs and the construction of the facilities that are needed for carrying out the educational programmes. The notion of education with production has been used by a number of countries including the former Soviet Union, Cuba, Botswana, Ghana and Zimbabwe just to name a few. The concept was popularised by the Botswana educationist Patrick Van Rensburg through the brigade system. Van Rensburg (1981) is of the view that the school is the centre of development and provides opportunity for better learning. The school curriculum he proposes should include practical subjects such as agriculture, carpentry, brick laying, metal work, technical drawing and typing. Singh (1998:8) notes that some important factors in the education with production equation include the motivation for learning with production and the use of the vocational and technical training to partially meet some of the cost of training for the institutions in question.

The main objective of this paper was to find out how the concept of education with production is being practised at 
Tiger Kloof Educational institution and how the concept can be used as a model to teach adults and youth in rural South Africa and elsewhere in Africa sustainable livelihoods. Van Rensburg (1977) advocates for ways by which education with production as an economic concept can be incorporated in the school curriculum and education and training activities of programmes and institutions. He is of the view that productive activities of educational institutions can assist them to improve their finances, and the potential for linkages between education and employment and sustainable livelihoods. The researcher was motivated to conduct this research as a contribution to addressing the problems of poverty, unemployment and inequality among adults and the youth in rural the areas of Africa. This paper uses the qualitative approach through interviews to find out how the principle of education is being applied in the Tiger Kloof context. The findings indicate that the concept of education with production is being applied in a lot of areas in the school but it came out that the students are not very much involved in the actual activities as there are workers who do most of the productive economic activities. The paper recommends that educational institutions in rural areas in Africa apply this principle to teach adults and youths on how they can use the resources they have in abundance (the land) to engage in productive economic activities in addressing some of the socio-economic challenges they face.

\section{Conceptual Framework}

The conceptual framework underpinning this study is education with production which is analysed from two contexts namely 'learning' and 'work'. Van Rensburg (1977) is of the view that depending on the context, the combination of education with production can have tremendous economic, social and pedagogical benefits on individuals and communities. He avers that this can be achieved through the incorporation of productive work into the school curriculum and the activities of educational and training institutions and programmes; or it could mean the provision of serious and organised educational programmes for those existing and new ones. Singh (1998) points out that education and training form part of the broader domain of learning, whereas productive enterprise forms part of the world of work. The combination of the two perspectives in education with production he adds is to enhance and re-enforce the systematic and reflective learning in improving the relevance of education to later in employment and self employment as well as ensuring sustainable development in local communities and regions. Education is most viewed in terms of the processes of acquiring knowledge, attitudes and values whereas training is most often associated with the acquisition of specific job-related and occupational skills. In effect the two concepts are very closely related as it is difficult to demarcate where one ends and the other begins. The concept of education with production if well applied could have a lot of social, economic and educational value in most educational institutions in Africa as most of the schools and communities have access to natural resources on which are used for most productive activities.

Van Rensburg is of the view that the development of mental skills is not only limited to verbalisation of teaching the school syllabus in the sequence in which it appears but also teaching the production process practically, thereby developing and promoting other mental skills. He observes that the social dimension of the education with production is closely related to both the economic and pedagogical aspects as education is seen all the time as a social process in which the organisation and control of production and the use of technology are a fundamental a source of group and individual consciousness. In the same vein, Unesco (2012) emphasise that the third Education for All (FFA) goal focuses on "the learning needs of all young people and adults". Unesco (2012) adds that there is the urgent need to develop the skills of young people and adults as young people and adults irrespective of their background, require skills that prepare them for decent jobs so that they can thrive and participate fully in society. Education with production can be a step in ensuring that young people and adults acquire wide range of skills that can improve their job prospects.

This concept is relevant to the Tiger Kloof situation and possibly can be applied in most rural schools where land and other productive resources are available that can be used in education with production as well as the difficulty of the youth and adults to find employment in the private and government sectors. In Tiger Kloof, the school is endowed with a 1400 hectre plot with grazing and arable land where animals and vegetables are produced. The most visible aspect of education with production as applied at Tiger Kloof is based on the principles of permaculture and holistic management. Neely and Butterfield (2004) note that holistic management "is about reducing risk in decision making by a holistic goal using planning procedures that create a balance between financial, ecological and social factors". The word permaculture according to Wegweiser (2011) is a portmanteau of permanent and agriculture/culture which can be defined as "the conscious design and maintenance of agriculturally productive ecosystems which have diversity, stability and resilience of natural ecosystems. It is the harmonious integration of landscape and people providing food, energy, shelter and other material and non-material needs in a sustainable way". In effect the two concepts are close and involve doing what one has to do to achieve one's holistic goals. The school as a Round Square school requires the learners to engage in 
certain practical service oriented activities as extramural activities. Some of these include brick laying, taking care of the environment, being part of a service activity, the environmental club and producing vegetables and training of farmers in the neighbouring towns and communities.

\section{Problem Statement}

Tiger Kloof as an educational institution practises the concept of education with production to a certain extent as the school is involved in a number of productive activities ranging from cleaning of plates by students in the dining hall, the maintenance unit that trains artisans and builds and does all the repair work, taking care of the environment and engaging in farmer training and training the youth about the environment and land care. There is cattle production which is now saving the institution a lot of money as well as the vegetable gardening producing for the kitchen. This practice equips the local community and the learners in productive activities that enable some of them to apply in their lives later.

The main research question from the statement above is: How is Tiger Kloof applying the concept of education with production and to what extent is it impacting on the lives of the learners and the surrounding communities? Sub-questions

- What are the main productive activities that that are linked to education at Tiger Kloof?

- How are the different stakeholders involved in the education with production activities?

- How effective is the concept education with production at Tiger Kloof?

\section{Methodology}

This study used the qualitative method of enquiry through semi-structured interview to collect data from respondents. The purposive sampling technique was used to interview 10 learners from the senior and FET phases, two managers (maintenance and agricultural) sections and three beneficial farmers from Tiger Kloof's farmer training programmes. The researcher conducted the interviews at Tiger Kloof with the farm manager, the maintenance manager and the students. The three farmers who have been trained at the school in farming were also interviewed in two nearby towns. The study adopts a phenomenological position that attempts to understand people's perceptions, perspectives, and understanding of a particular situation (Leedy and Ormrod, 2005). It is not easy to understand human beings and their environment from data obtained by non-human means of collection and quantitative analysis. The qualitative approach allows a researcher to probe 'atypical' and 'idiosyncratic' responses which no pre-existing instruments(s) can accomplish. The human instrument is the only data collection instrument which is multifaceted enough to and complex enough to capture the important elements of a human person or activity (Maykut and Morehouse, 1994)

\subsection{Population}

Population is defined as the aggregate of cases with a common assigned criterion and features as subjects for a study. The target population for this study is all the learners who are currently registered at the senior and FET phases of the school, the managers of the agriculture and maintenance units of the school, all the farmers who have been trained by the school.

\subsection{Sampling}

The non-probability sampling approach is ideal for such a study. In non probability sampling the researcher has no way of ensuring that each of the elements of the population will be represented in the sample. In this study the convenience sampling technique is used because of the difficulty involved in including all the people in the programme. Besides that the researcher needed to obtain information from key informants who could give relevant information on the phenomenon that is being investigated. In addition to that money and time constraints made the researcher to use his contacts in the school to get access to all the participants.

\subsection{Data collection}

The researcher used his contacts at the school where he spent three days in the first week of June 2013. He conducted a focus group with the learners. Another interview was conducted with the managers of the two units on the same day at 
the school. The farmers were interviewed in two towns (Ganyesa and Tlakgameng) about 70 kilometres from Vryburg. The convenient sampling is a technique in which particular settings, persons or events are selected deliberately in order to provide information that cannot be obtained from other choices (Wilson, 2010). In this study the participants were students, farmers, managers of organisations and managers of production units at Tiger Kloof. The interviews were tape recorded in addition to a journal that was used to record issues which frequently occurred during the interviews with the participants. Each of the interviews with the managers lasted for between twenty and thirty minutes. The focus group lasted for forty-five minutes. The interview with the farmers lasted for 30 minutes each.

\section{Results and Discussion}

The analysis of the semi-structured interviews was done through content analysis which identified common themes, issues and words that recurred in the interviews. The transcripts of the interviews were analyzed to determine the overall picture of the cases as well as integrating the meanings of issues in typical experience. Some few responses from the interviews were translated verbatim to capture their experiences and feelings. The study found out that there are a lot of activities that take place at the institution which can be classified under what is referred to as education with production although the activities are not referred as such to the concept directly. Some of the activities include farming, education and training of both the youth and adults in productive activities, rendering services to the school and neighbouring communities etc. The study also identified different stakeholders that are involved in the application of the concept at the institution such as workers in the maintenance unit, the learners in educational and practical activities and the agriculture unit of the institution as one of the visible activity. Education with production to a large extent is being applied at Tiger Kloof and appears to be effective to a large extent. The finding from the interviews from the participants are summarised below.

\subsection{The farm manager}

The farm manager explained that he is involved with a number of productive activities including managing the cattle farm, the vegetable garden, farmer training and conducting environmental education for high schools in collaboration with the Department of Agriculture and Environmental Affairs. He indicated that he started with 50 indigenous cattle called the nguni at the farm three years ago. He now has 150 of the breed. He has had the vegetable garden which is supplies the kitchen, sales to workers and educators as well and supplying the organisations the school partners with. He indicated that he conducts the training of the farmers at the school and makes the follow ups in the villages from time to time. The environmental education he indicated is conducted for learners across the district for learners in the senior phase from different schools which the Department of Agriculture and Environmental Affairs funds.

\subsection{Learners}

During the focus group, the learners indicated the different activities they were engaged in which for them was part of the services they perform as part of their activities as learners in a round square school. Some of the activities include cleaning the school and its surroundings, cleaning their plates after meals, and participating in one or more activities of practical nature as extra-mural activities such as brick laying, going for services in the orphanages and old age homes etc. When asked about if they were aware of the concept of education with production, they simply understood it to be service which they enjoyed doing. Some of the learners indicated that they are given the opportunity to participate in the running of the tuck shop in the school which affords them the opportunity to learn how to run businesses. The learners were however of the view they are not directly involved in the farming and the main productive activities that take place in the institution. Some of them expressed the view that they are interested in knowing and learning more about the farming activities as they are mostly from farming communities.

\subsection{The manager of the maintenance unit}

The maintenance unit according to the manager has restored most of the dilapidated infrastructure which lay in ruins for over twenty five years. The unit is involved in building new structure and maintaining and restoring old ones, plumbing, electrical, carpentry and cleaning and maintaining the campus as well as mending the fences etc. They are also involved in the training for the Department of Labour of artisans as well as giving practical skills for learners who register to learn 
practical skills as part of their extra-mural activities.

\title{
5.4 Farmers
}

The three farmers who were interviewed indicated that the training they had three years back at Tiger Kloof in permaculture and general farming is helping them to feed their families, create employment in the areas and addressing the problems of poverty and food security. They specifically mentioned the use of permaculture in vegetable farming and rearing animals as particularly productive in their rural circumstances. The interviews from the participants are classified under the following themes, education and training, sustainable livelihoods and service.

\subsection{Theme 1: Education and training}

Education with production as applied by Tiger Kloof is assisting different stakeholders in the community to acquire education and training to better their living conditions on the basis of the asset-based approach of the school. The assets in this regard include the human capital, land and other economic and physical resources the institution processes. For example the maintenance manager showed all the maintenance work and the new structures they have been constructed since the school was reopened in 1995. He indicated that he and his foreman had trained all the staff in his unit i.e. plumbers, electricians, bricklayers as well as hundreds of other artisans who were employed elsewhere as well as those having their own construction businesses. The unit manager for example said

\begin{abstract}
Just look at all these structures, they were just in ruins but we have restored them to what you see now. We trained all our maintenance staff here and we are able to save the institution a lot of money. We are very busy but we still make provision to teach the learners who are interested in the trades carpentry, bricklaying etc as extra-mural activity.
\end{abstract}

The farm manager took the researcher around the farm and the vegetable garden where he explained the approach they use which is based on permaculture principles. He indicated that from 50 cattle just three years back, he now has 150 and saving the kitchen a lot as they are able to supply meat and vegetables at almost half the price. Besides that the unit has been training local farmers in permaculture in collaboration with the North West Department of Agriculture and Environmental Affairs. This initiative does not only bring financial rewards to the institution but most importantly it is assisting in poverty alleviation and food security in the surrounding towns and villages. The farm manager for instance said

Before we introduced this training, a lot of these farmers had difficulty in utilising their plots and farms productively but
just go round and see that these people are now supplying the schools, local supermarkets and communities with food.
Poverty levels have dropped considerably for most of the participants. More people are applying to join the programme.

The researcher met the the farmers and observed the amount of food and animals they are producing around their homes and fields. One of the farmers was full of praise for the farm manager and the school for giving them the training which she said had changed her life. She shouted with joy

Before I met mogotsi (my friend), I used to borrow most often to feed my family but for the past two years, I am able to give food and sometimes financial support to members of our community who are struggling. This training has enabled me to self-sufficient and my cattle and goats have now doubled.

\subsection{Theme 2: Sustainable livelihoods}

The use of education with production at Tiger Kloof is contributing to sustainable livelihoods for the school and the community. The productive activities in the form of agricultural production are now generating income through the farmer training programme. In addition to that the school is using its assets to produce some of the food especially meat in cost effective manner thereby ensuring sustainability. The maintenance unit according to the unit manager is able to build and maintain the facilities at almost half the cost that could be charged by external contractors. The farmer training which is based on permaculture is helping in poverty alleviation in the surrounding communities as well as ensuring the sustainable use of the natural resources the communities have at their disposal. One of the farmers indicated how applying he is ensuring the sustainable use of the land this way 
You take care of the land and the land takes care of you. I used to kill the birds and the worms that came to the garden but I now lure them to come there as I have learnt that they are my friends

\subsection{Theme 3: Services}

The learners are engaged in education with production in diverse ways but to most of the participants it is a matter of rendering services to themselves and the communities. Some of the activities such as washing of the plates after meals, working in the orphanages and old people's homes and cleaning the environment have become part of their lives. These are productive activities which could run into thousands of rands if quantified in monetary terms. This spirit of service or volunteerism is important for the youth to become responsible citizens in the future.

\section{Conclusion}

This study examined how education with production is being applied at Tiger Kloof Educational institution in the North West Province of South Africa. The qualitative research method was used in the form of individual and focus group interviews for the participants who include 10 learners for the focus group, and 2 managers from some of the productive units of the institution and three farmers who have benefited from the school's farmer training programme. The main findings from the study included: evidence of the concept of education with production being applied at various sections of the institution although the concept has not been used for those activities; the activities are yielding economic returns as well as contributing to sustainable development in the school and surrounding communities; the learners are involved to a limited extent in the productive activities; the institution does not have adequate resources to help many of the surrounding communities that have shown interest in the programme. The researcher acknowledges that the concept was used elsewhere which appears not to have worked well possibly because of using it to advance some political agendas e.g. (the workers brigade system in Ghana) but at Tiger Kloof and Botswana, there is enough evidence to show that the principle can be used in the teaching and learning and ensuring sustainable development in rural communities.

\section{Recommendations}

The following are recommended for improvement in the use of education with production at Tiger Kloof and elsewhere:

- The learners should be involved more in the agricultural and skill training activities as they expressed interest in the farming venture which has proven to be very lucrative for the school as most of the students are from rural communities

- The school should consider and introduce agricultural science in the school curriculum so that the learners who want to pursue agriculture as career could gain the needed skills through the school's activities

- More training of adults from the neighbouring communities should be intensified to afford people the opportunity to learn how to use their land productively to support themselves and their families

- The school should endeavour to showcase what it is doing and source funds from government, the private sector and NGOs to enable it to do more to combating poverty and unemployment in rural communities.

\section{References}

Leedy, P.D. \& Ormrod, J.E. (2005). Practical research. Planning and design, $8^{\text {th }}$ Edition. New Jersey: Pearson Merrill Prentice Hall. Maykut, P. \& Morehouse, R. (1994). Beginning qualitative research. A philosophical and practical guide. London: The Falmer Press. Singh, M. (1998). School enterprise: Combining vocational learning with production. UNEVOC. UNESCO. Unesco. (2012). Youth and skills: Putting education to work. EFA Global Monitoring Report 2012. Paris: Unesco Publishing. Van Rensburg, P. (1977). Combining education and production: situating the problem. Prospects, Quarterly Review of Education, Vol. VII No. 3, 1977. UNESCO, PP. 352-354.

Van Rensburg, P. (1981). The Right Livelihood Award, 1981.

Wilson, J. (2010). Essentials of business research. A guide to doing your project. Los Angeles: Sage.

Wegweiser, C. (2011). A feasibility study concerning the establishment of a public permaculture park in Uppsala, Sweden. Master's thesis submitted at Uppsala Universitet. 